\title{
SH21 - Reformas constitucionales de 1993 y cambios en el diseño institucional del estado guatemalteco
}

\author{
Dabroy, Jahir \\ Arlen de León \\ Instituto de Investigaciones Políticas y Sociales \\ Escuela de Ciencia Política \\ Universidad de San Carlos de Guatemala
}

\section{Resumen}

- 1 presente trabajo tiene como objetivo determinar las principales implicaciones que tuvieron para el sistema Dolítico guatemalteco las reformas constitucionales de 1993 y los cambios en el diseño institucional del Estado de Guatemala; para ello se realizó una investigación bibliográfica, documental y hemerográfica, así como entrevistas semiestructurada a actores clave del proceso. Dentro de los resultados se precisan los cambios en 34 artículos de la Constitución Política, que se catalogaron en dos sentidos: las reformas políticas y las reformas financieras para el Estado de Guatemala. Esto permite discutir el por qué se dan esos cambios, cuando lo que se buscaba era de un inicio garantizar la democracia en el país y las principales implicaciones producto de la depuración en el Congreso de la República y la creación de las comisiones de postulación.

Palabras clave: Reformas constitucionales, Estado, sistema político, instituciones, democracia.

\begin{abstract}
$\mathrm{T}$ his paper aims to determine the main implications that had for the Guatemalan political system the constitutional reforms of 1993 and changes in the institutional design of the State of Guatemala. A bibliographic research, documentary and newspaper archives, as well as semi structured interviews with key actors of the process was carried out: political reforms and financial reforms for the State of Guatemala, within results changes in 34 articles of the Constitution, which were classified in two ways required. This lets discuss why these changes occur, when what was sought was initially ensure democracy in the country and the main implications product debugging on the Congress and the creation of the nominating committees.
\end{abstract}

Keywords: Constitutional reforms. State. Political system. Institutions. Democracy 